\section{IS AGGRESSIVE DISTAL REPAIR NECESSARY IN AORTIC DISSECTION SURGERY?}

To the Editor:

Congratulations to Kobuch and colleagues ${ }^{1}$ for their valuable study. The general approach in surgical repair of the type A aortic dissection is aggressive proximal aortic repair., ${ }^{2,3}$ Nevertheless, it is controversial whether distal aortic repair is risky for reoperation. Some studies have suggested that performing distal aortic repair within the initial operation has no effect on reoperation risk, ${ }^{3}$ whereas some other studies have emphasized that aggressive repair to the aortic arch or distally should be performed within the first operation to avoid reoperation., ${ }^{2,4}$ One or more intimal tears occur in the pathogenesis of the aortic dissection. If the intimal tear were to appear in multiple sites, aggressive distal aortic repair would not be useful in avoiding the reoperation risk. Although the intimal tear usually propagates antegradely, it may do so retrogradely. An intimal tear distal to the replaced aortic segment would propagate retrogradely and cause aneurysmal dilation, either at the anastomosis site or distally. In light of these data, the issue of how aggressively to perform distal aortic repair should be discussed. In addition, we wonder whether aggressive distal aortic repair had an impact on the reoperation risk in the study by Kobuch and colleagues. ${ }^{1}$

Orhan Gokalp, $M D^{a}$

Ismail Yurekli, $M D^{b}$

Serkan Gur, $M D^{c}$

${ }^{a}$ Department of Cardiovascular Surgery

Faculty of Medicine İzmir Kâtip Çelebi University ${ }^{b}$ Department of Cardiovascular Surgery

Izmir Atatürk Education and Research Hospital

${ }^{c}$ Department of Radiology İzmir Şifa Hospital Izmir, Turkey

\section{References}

1. Kobuch R, Hilker M, Rupprecht L, Hirt S, Keyser $\mathrm{A}$, Puehler T, et al. Late reoperations after repaired acute type A aortic dissection. J Thorac Cardiovasc Surg. 2012;144:300-7.

2. Pugliese P, Pessotto R, Santini F, Montalbano G, Luciani GB, Mazzucco A. Risk of late reoperations in patients with acute type A aortic dissection: impact of a more radical surgical approach. Eur J Cardiothorac Surg. 1998;13:576-81.

3. Kirsch M, Soustelle C, Houël R, Hillion ML, Loisance D. Risk factor analysis for proximal and distal reoperations after surgery for acute type A aortic dissection. J Thorac Cardiovasc Surg. 2002;123:318-25.

4. Sun L, Qi R, Chang Q, Zhu J, Liu Y, Yu C, et al. Surgery for acute type A dissection with the tear in the descending aorta using a stented elephant trunk procedure. Ann Thorac Surg. 2009;87:1177-80.

http://dx.doi.org/10.1016/ j.jtcvs.2012.05.082

\section{Reply to the Editor:}

Gokalp and colleagues stated an interesting hypothesis relating the number of entry sites to the necessity of distal aortic repair. We cannot argue in favor or against this assumption because the respective data are not available for our study. However, from a clinical point of view, other factors certainly are important for the selection of the applied surgical technique in acute type A aortic dissection. With regard to the hypothesis, we would think the opposite: If there is only 1 proximal entry, the chance of cure with a mere replacement of the ascending aorta is high. However, if there are multiple entries, a more extended aortic repair is necessary because all entry sites should be resected. A complete arch replacement and elephant trunk procedure would avoid reoperation with a high likelihood.

$$
\begin{array}{r}
\text { Christof Schmid, MD } \\
\text { Rainer Kobuch, MD } \\
\text { University Medical Center } \\
\text { Regensburg } \\
\text { Regensburg, Germany } \\
\text { http://dx.doi.org/10.1016/ } \\
\text { j.jtcvs.2012.06.016 }
\end{array}
$$

\footnotetext{
The Editor welcomes submissions for possible publication in the Letters to the Editor section that consist of commentary on an article published in the Journal or other relevant issues. Authors should: - Include no more than 500 words of text, three authors, and five references. - Type with double-spacing. - See http://jtcs.ctsnetjournals.org/misc/ifora.shtml for detailed submission instructions. - Submit the letter electronically via jtcvs.editorialmanager.com Letters commenting on an article published in the JTCVS will be considered if they are received within 6 weeks of the time the article was published. Authors of the article being commented on will be given an opportunity of offer a timely response ( 2 weeks) to the letter. Authors of letters will be notified that the letter has been received. Unpublished letters cannot be returned.
} 